\title{
HUBUNGAN PERSEPSI PENDERITA KANKER SERVIKS TERHADAP PEMAHAMAN TENTANG PEMANFAATAN JUS IKAN GABUS (OPHIOCEPHALUS STRIATUS)
}

\author{
${ }^{1}$ Sri Herlina, ${ }^{2}$ Dewi Martha Indria \\ ${ }^{1,2}$ Program Studi Pendidikan Dokter Fakultas Kedokteran \\ Universitas Islam Malang \\ e-mail : ${ }^{1}$ sriherlina@unisma.ac.id,${ }^{2}$ dewimarthaindria@unisma.ac.id
}

\begin{abstract}
Abstrak
Latar Belakang: Perkembangan penyakit kanker setiap tahun terus meningkat. Tercatat sekitar 15.000 kasus kanker serviks terjadi di Indonesia. Penggunaan ikan Gabus sebagai alternatif pengobatan bersumber dari protein hewani penting diinformasikan untuk meningkatkan asupan nutrisi bagi penderita kanker karena tinggi kandungan albumin, asam amino esensial serta nutrisi yang baik untuk imunitas atau daya tahan tubuh.

Tujuan: Penelitian ini bertujuan untuk melihat hubungan persepsi penderita kanker serviks terhadap pemahaman pemanfaatan jus ikan gabus (ophiocephalus striatus) Metode: Desain penelitian cross sectional study dilakukan pada 8 penderita kanker serviks dengan teknik skrining dari catatan rekam medik pasien di Puskesmas M,D,P diKota Malang. Teknik pengambilan sampel yang digunakan non-probability sampling berupa purposive sampling. Analisis data menggunakan uji Fisher exact test.

Hasil: Karakteristik penelitian menunjukkan bahwa responden terbanyak berusia 41-50 tahun dengan pendidikan SMA 50\%. Hasil distrbusi frekuensi persepsi tentang kanker dipahami dengan baik sebesar 87,5\%, sedangkan pemahaman tentang pemanfaatan jus ikan gabus sebagai nutrisi bagi penderita kanker masih rendah yaitu sebesar $12,5 \%$.

Kesimpulan: berdasarkan hasil uji analisis data disimpulkan bahwa tidak terdapat hubungan antara persepsi penderita kanker terhadap pemanfaatan jus ikan gabus $(p>0,05)$. Pemanfaatan ikan gabus sebagai terapi nutrisi suportif dapat mempercepat proses penyembuhan para penderita kanker yang menjalani perawatan paliatifnya sebagai upaya peningkatan kualitas hidup pasien.
\end{abstract}

Kata kunci: persepsi, kanker serviks, ikan gabus

\begin{abstract}
Background: The development of cancer continues to increase every year, recorded around 15,000 cases of cervical cancer occurred in Indonesia. Snakehead Fish (Ophiocephalus striatus). The using of Snakehead Fish can be used as alternative treatment that was derived from animal protein is important to inform to enhance nutrition for cancer suffer because it is known that it has high albumin content, contains essential amino acids and good nutrients that are good for immunity.

Aim:This study aims to determine the correlation between perceptions of cervical cancer patients during palliative treatment to the consumption of snakehead fish juice Methods: The cross-sectional study was carried out on 8 cervical cancer patients as respondent from secondary data (medical record) that were get from Puskesmas $M, D, P$ in Malang. The sampling technique was non probability sampling (purposive sampling). Data analysis used the Fisher exact test.
\end{abstract}


Results: The research character show that many of respondentis 40-50 years old with $50 \%$ senior higt school degree. The distrubution result is frequency of perception about cancer in a good understanding in 87,5\% while the understanding about using snakehead fish as a nutrition to cancer suffer is still low in 12,5\%.

Conclusion: This study showed that there is no relationship between perceptions of cervical cancer patients to the consumption of snakehead fish juice in their daily diet ( $p$ $>0,05)$. So, it is expected by increasing the consumption of snakehead fish in their daily diet, it can be work as supportive nutrition therapy in palliative treatment to increase cancer patient's quality of life.

Keywords: perception, cervical cancer, snakehead fish

\section{PENDAHULUAN}

Kanker serviks merupakan salah satu penyebab kematian utama di seluruh dunia yang banyak membunuh kaum perempuan. Menurut penelitian World Health Organization (WHO), di seluruh dunia terdapat 490.000 kasus kanker serviks dan mengakibatkan 240.000 kematian tiap tahunnya, $80 \%$ dari angka itu terjadi di Asia. Setiap 1 menit terdapat 1 kasus baru dan setiap 2 menit terdapat 1 kematian ${ }^{(1)}$. Berdasarkan data Riset Kesehatan Dasar, Badan Litbangkes Kementerian Kesehatan Republik Indonesia diperkirakan sekitar 3256 kasus baru penderita kanker di tahun 2013, berada pada kelompok umur 35-75 tahun, yaitu sebesar $5 \%$ kasus $^{(2)}$. Data pengidap kanker tahun 2016 sebesar 17,8 juta jiwa menjadi 21,7 juta jiwa di tahun 2017, artinya terjadi peningkatan $3,9 \%$ jumlah pengidap kanker ${ }^{(3)}$, diperkirakan pada tahun 2030 akan terjadi lonjakan penderita kanker di Indonesia sampai tujuh kali lipat.
Jumlah penderita kanker yang meninggal juga semakin memprihatinkan ${ }^{(2,4)}$.

Penyebab kanker serviks adalah infeksi Human Papiloma Virus (HPV). Pada stadium awal, kanker serviks tidak menunjukkan adanya gejala. Namun, pada stadium lanjut dapat ditemukan gejala terjadinya perdarahan saat melakukan hubungan suami istri, keputihan yang berbau dan nyeri pada perut bagian bawah. Kurangnya konsumsi sayur dan buah, kebiasaan mengonsumsi makanan dibakar atau dipanggang dan mengonsumsi makanan hewani berpengawet cenderung menjadi faktor risiko tertinggi terjadinya kanker. Proporsi penduduk yang merokok, obesitas, dan sering mengonsumsi makanan berlemak tertinggi juga menjadi faktor predisposisi penyakit kanker.

Berbagai upaya pengobatan dan pencegahan seperti pencegahan primer melalui edukasi dan vaksinasi serta pencegahan sekunder yaitu skrining lesi pra kanker melalui pemeriksaan papsmear, 
IVA (Inveksi Visualisasi Asetat) atau kolposkopi bahkan pengobatan radioterapi sudah banyak dilakukan, akan tetapi prevalensi kasus kanker serviks masih tinggi.

Terobosan yang dikembangkan saat ini yaitu menerapkan konsep perawatan paliatif dan promosi kesehatan menjadi salah satu upaya untuk mengurangi tingkat keparahan gejala penyakit kanker serta memberikan

alternatif pencegahan dengan menggunakan Jus Ikan Gabus. Ikan gabus (Ophiocephalus striatus) merupakan ikan air tawar berkhasiat untuk pengobatan secara tradisional dan termasuk makanan kesehatan. Sejak dulu sudah dipercaya sebagai bahan obat seperti di Sulawesi Selatan, mengonsumsi ikan gabus baik bagi perempuan yang baru melahirkan, sedangkan di Tana Toraja kebiasaan memberikan ikan sejak kecil kepada anakanak dipercaya dapat meningkatkan kekebalan tubuh anak ${ }^{(5)}$.

Penggunaan jus ikan gabus (Ophiocephalus striatus) dipercaya berkhasiat untuk pengobatan secara tradisional dan dapat meningkatkan kekebalan tubuh anak-anak ${ }^{(6)}$. Kemampuan ikan gabus sebagai obat tradisional diduga berasal dari kandungan protein yang tinggi $25,5 \%$ dibandingkan ikan sarden $21,5 \%$.
Albumin yang cukup tinggi, lemak, air dan

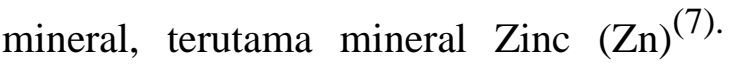
Aktivitas antipiretik ikan gabus diduga terkait dengan jalur munculnya respon nyeri, sehingga ikan gabus juga berperan sebagai analgetik. Pada jalur respon nyeri terdapat keterlibatan reaksi oksidasi. Reaksi oksidasi melibatkan perpindahan elektron dan pembentukan oksidan ${ }^{(8)}$. Untuk menghambat proses reaksi oksidasi agar tidak berlangsung diperlukan senyawa inhibitor, misalnya antioksidan yang berasal dari aktivitas katalase. Antioksidan merupakan senyawa yang dapat menghambat oksidasi secara bermakna berupa antioksidan yang dibentuk oleh senyawa Zinc dalam rangka mempertahankan hidupnya terhadap oksidan.

Meskipun demikian, berbagai pengobatan menggunakan ekstrak hewan sebagai alternatif penyembuhan "pengobatan kampung" perlu dikaji berbagai bukti ilmiah yang dimilikinya ${ }^{(9)}$. Berdasarkan pemikiran di atas, penting dilakukan kajian dasar tentang analisis persepsi penderita kanker selama pengobatan terhadap pemanfaatan jus Ikan gabus dengan harapan peningkatan asupan gizi yang baik untuk meningkatkan kualitas hidup pasien. 


\section{METODE PENELITIAN}

Penelitian menggunakan desain studi cross sectional ${ }^{(10)}$. Penelitian dilaksanakan di ketiga Puskesmas M, D, P di Kota Malang. Populasi adalah seluruh penderita kanker serviks di terdata di ketiga Puskesmas tersebut, berdasarkan data rekam medis tahun 2017-2018 sebanyak 14 pasien kanker. Sampel pada penelitian yang terlibat sebanyak 8 pasien penderita kanker serviks dengan teknik skrining dan pelacakan sesuai dengan alamat dan data berobat yang tercatat di rekam medik pasien di Puskesmas tersebut. Pengambilan sampel dilakukan setelah mendapat persetujuan responden (informed consent) disertai wawancara mendalam untuk komunikasikan informasi kesehatan baik langsung maupun tidak langsung dengan teknik non-probability sampling berupa purposive sampling yaitu suatu teknik penetapan sampel dengan cara memilih sampel diantara populasi sesuai dengan yang dikehendaki peneliti ${ }^{(10)}$, sehingga sampel tersebut dapat mewakili karakteristik populasi yang telah dikenal sebelumnya. Kriteria inklusi yaitu bersedia menjadi responden, terdiagnosa kanker direkam medis di tiga Puskesmas M, D, P, kemudian berdomisili di ketiga wilayah Puskesmas tersebut, sedangkan Ekslusi yaitu Pasien tidak bersedia mengikuti seluruh kegiatan penelitian dan saat pelacakan tidak bersedia didata, serta domisili atau alamat yang diberikan tidak lengkap dan tidak sesuai wilayah penelitian.

Instrumen penelitian yang digunakan berkaitan dengan persepsi tentang pengetahuan tentang pemahaman penderita kanker serviks tentang penyakit kanker terdiri dari 10 pertanyaan dengan nilai skor. Jawaban benar diberi nilai 1 dan jawaban salah diberi nilai 0 . Total nilai dibagi nilai maksimal kemudian dikali

100\%. Menurut Rahma 2010 mengelompokan 2 kategori pengetahuan yaitu Baik $>50 \%$ dan kurang baik $<50 \%{ }^{(11)}$, sedangkan pemahaman tentang Persepsi pemanfaatan ikan gabus menggunakan instrumen kuesioner dengan 4pertanyaan berkaitan dengan, penggunaan jus ikan gabus, kesedian menggunakan ikan gabus, kandungan gizi dan mengetahui informasi tentang ikan gabus berkhasiat untuk meningkatkan imunitas tubuh. Skor penilaian di nilai 1 jika jawaban benar dan 0 jika jawaban salah. Data penelitian yang diperoleh dianalisis secara univariat dan bivariat dengan uji Fisher exact test menggunakan program SPSS Versi 23. 


\section{HASIL DAN PEMBAHASAN}

\section{Karakteristik Subjek Penelitian}

Karakteristik responden yang terlibat dalam penelitian ini dapat dilihat pada Tabel 1. Berdasarkan karakteristik responden, terlihat bahwa responden terbanyak berusia 41-50 tahun sebesar

75\%. Menurut Riskesdas (2013) menyebutkan bahwa prevalensi kanker meningkat seiring dengan bertambahnya usia. Menurut Diananda (2007), usia di atas 35 tahun memiliki risiko tinggi terhadap kejadian kanker. Semakin tua usia seseorang maka semakin meningkat risiko terjadinya kanker ${ }^{(11)}$.

\section{Tabel 1. Karakteristik Subjek Penelitian}

\begin{tabular}{|c|c|c|}
\hline \multirow[t]{2}{*}{ Karakteristik Subjek } & \multicolumn{2}{|l|}{ 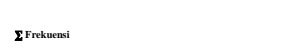 } \\
\hline & $n=8$ & $\%$ \\
\hline \multicolumn{3}{|l|}{ Usia } \\
\hline 30-40 tahun & 1 & 12,5 \\
\hline 41-50 tahun & 6 & 75 \\
\hline 51-60 tahun & 1 & 12,5 \\
\hline \multicolumn{3}{|l|}{ Tingkat Pendidikan } \\
\hline Sekolah Dasar & 1 & 12,5 \\
\hline SMP & 1 & 12,5 \\
\hline SMA & 4 & 50 \\
\hline Perguruan Tinggi & 2 & 25 \\
\hline \multicolumn{3}{|l|}{ Pekerjaan } \\
\hline IRT & 3 & 37,5 \\
\hline Karyawan & 2 & 25 \\
\hline Pendagang & 2 & 25 \\
\hline Pensiun & 1 & 12,5 \\
\hline \multicolumn{3}{|l|}{$\begin{array}{l}\text { Lama terdiagnosa dan } \\
\text { pengobatan }\end{array}$} \\
\hline$<1$ tahun & 2 & 25 \\
\hline$>1$ tahun & 6 & 75 \\
\hline Total & 8 & 100 \\
\hline
\end{tabular}

Pendidikan tertinggi adalah tamatan SMA sebanyak 50\%. Tingkat pendidikan merupakan salah satu faktor yang akan mempengaruhi keberhasilan seseorang dalam memahami informasi kesehatan. Hal ini menunjukkan tingkat pendidikan penderita kanker sudah cukup tinggi, responden telah menyelesaikan program wajib belajar sembilan tahun. Dengan tingkat pendidikan yang tinggi, responden akan lebih dapat menerima informasi sehingga pengetahuan dan wawasannya akan menjadi luas. Rendahnya pendidikan (SD 12,5\%) jika dikaitkan dengan kesadaran maka akan semakin buruk status kesehatan. Hal ini terjadi juga pada penderita kanker, semakin rendah pendidikannya maka akan cenderung tidak mengetahui gejala akan penyakit tersebut. Ketidaktauan akan gejala penyakit kanker, maka akan semakin berisiko terhadap kesehatannya karena tidak menyadari adanya suatu penyakit didalam tubuh penderita. Pekerjaan terbanyak dari responden adalah sebagai ibu rumah tangga (IRT) sebanyak $37,5 \%$ dengan lama menderita atau terdiagnosa kanker > lebih dari 1 tahun yang sudah melakukan pengobatan secara rutin di rumah sakit maupun Puskesmas, penderita kanker tidak

memiliki riwayat keluarga yang 
mengalami kondisi serupa, sehingga upaya preventif dan kuratif terus dilakukan dengan harapan segera sembuh dan sehat kembali.

\section{Distribusi Responden Berdasarkan Persepsi Pengetahuan Penderita Kanker}

Persepsi responden menyebutkan bahwa penyebab utama atau faktor resiko terjadinya kanker dipahami dengan baik misalnya informasi berkaitan dengan terlalu banyak konsumsi penyedap rasa $(66,7 \%)$, pada makanan jenis mecin merupakan contoh pemicu timbulnya kanker sehingga responden berusaha menghindari berbagai penyedap rasa pada makanan sebagai upaya pencegahan pada kondisi yang lebih parah.

\section{Berdasarkan Tabel 2. Hanya} sebagian yang kurang (12,5\%) memahami tentang kanker serviks terutama terkait pemaparan tanda dan gejala yang dianggap responden hanya timbul benjolan meskipun sering disertai nyeri dan peradangan didaerah leher rahim. Pengalaman penderita sebelum pengobatan mempengaruhi pengetahuan seseorang saat penjalani terapi atau pengobatan saat ini. Persepsi penderita kanker $(65,7 \%)$ tentang upaya pencegahan dengan cara menjaga perawatan dan kebersihan diri terutama daerah vagina, termasuk pemenuhan gizi

seimbang perlu diperhatikan.

Tabel 2. Persepsi penderita kanker terkait pengetahuan pencegahan kanker $(n=8)$

\begin{tabular}{|c|c|}
\hline Kategori & $\begin{array}{l}\text { Persentase } \\
(\%)\end{array}$ \\
\hline \multicolumn{2}{|c|}{$\begin{array}{l}\text { Persepsi tentang pemahaman } \\
\text { definisi, gejala dan tanda }\end{array}$} \\
\hline Baik & 87,5 \\
\hline Kurang baik & 12,5 \\
\hline \multicolumn{2}{|c|}{$\begin{array}{l}\text { Persepsi tentang penyebab } \\
\text { dan faktor resiko }\end{array}$} \\
\hline Baik & 66,7 \\
\hline Kurang baik & 33,3 \\
\hline \multicolumn{2}{|c|}{$\begin{array}{l}\text { Persepsi tentang pencegahan } \\
\text { dan pengobatan Herbal, } \\
\text { vaksinasi, dan aktivitas fisik }\end{array}$} \\
\hline Baik & 65,7 \\
\hline Kurang baik & 34,3 \\
\hline $\begin{array}{l}\text { Persepsi tentang } \\
\text { petugas kesehatan } \\
\text { pengobatan }\end{array}$ & am \\
\hline Baik & 62,5 \\
\hline Kurang baik & 37,5 \\
\hline
\end{tabular}

Persepsi responden berkaitan dengan tindakan pengobatan dilakukan secara rutin 2 minggu sekali, pemahamannya sudah cukup baik, terlihat dari tindakan pemeriksan kesehatan dengan mendatangi pusat pelayanan kesehatan, artinya upaya preventif dan kuratif sudah dilakukan dengan baik oleh penderita kanker. Pencegahan juga dilakukan melalui kegiatan olahraga, senam pagi dan berjalan diketahui dengan baik, namun hanya sebagian responden yang melakukan.

Persepsi tentang penggunaan pengobatan herbal juga dipahami dengan baik, responden menyebutkan selain 
pengobatan medis penderita juga menggunakan herbal tumbuhan seperti daun binahong, pare, dan jahe untuk pengobatan dengan cara direbus, bahkan menggunakan cacing yang dihaluskan untuk menurunkan demam atau penghilang nyeri. Persepsi tentang peran petugas kesehatan sudah cukup baik. Namun

terdapat $(37,5 \%)$ responden yang menganggap bahwa perhatian petugas masih kurang dalam memberikan informasi tentang pemeriksaan IVA (Inspeksi Visual Asam Asetat), bahkan responden ada yang berinisiatif melakukan pemeriksaan dengan kesadaran sendiri karena penting untuk pendeteksi pertama leher rahim secara mudah, cepat dan murah, meskipun untuk diagnosa lanjutan kebanyakan pasien melakukan rujukan kerumah sakit terdekat walapun biaya yang dikeluarkan jauh lebih besar, dengan harapan pemulihan dari penyakit lebih cepat.

Berdasarkan Tabel 3. Menunjukkan Tingginya khasiat gizi dari ikan gabus menyebabkan banyak dimanfaatkan untuk alternatif pengobatan tradisional seperti meningkatkan daya tahan tubuh terutama bagi penderita kanker. Penelitian Santoso menyebutkan bahwa kandungan gizi ikan gabus terdiri atas $20 \%$ protein, $1.5 \%$ lemak, $0.2 \%$, karbohidrat, $1.3 \%$, mineral dan $77 \%$ air ${ }^{(12)}$. Hasil penelitian ini menunjukkan bahwa sebagian besar responden tidak memanfaatkan $(87,5 \%)$ jus ikan gabus baik dari kaldu maupun jus yang dibuat serbuk dari daging ikan tersebut $^{(13)}$. Menariknya terdapat salah satu responden (12,5\%) yang telah mencoba memanfaatkan jus ikan gabus dengan cara dibuat menjadi kaldu, sedangkan daging ikan yang kaya albumin, mineral dan tinggi protein dihaluskan seperti jus dijadikan lauk pauk dan dibuat pentol rebus.

Tabel 3. Distribusi Pemanfaatan Jus Ikan Gabus Pada Penderita Kanker ( $(n=8)$

\begin{tabular}{lc}
\hline Kategori & Persentase (\%) \\
\hline $\begin{array}{l}\text { Pemanfatan kaldu dan Jus } \\
\text { ikan gabus yang diolah }\end{array}$ & \\
$\quad$ - Dimanfaatkan & 12,5 \\
$\quad$ - Tidak & 87,5 \\
$\begin{array}{l}\text { Persepsi tentang informasi } \\
\text { ikan gabus meningkatkan } \\
\text { daya tahan tubuh (imunitas) }\end{array}$ & \\
$\quad$ - Mengetahui & \\
$\quad$ - Tidak tau & 62,5 \\
$\begin{array}{l}\text { Persepsi tentang kandungan } \\
\text { gizi ikan gabus (albumin, } \\
\text { protein, mineral) }\end{array}$ & 37,5 \\
$\quad$ - Mengetahui & \\
$\quad$ - Tidak tau & \\
$\begin{array}{l}\text { Persepsi penderita bersedia } \\
\text { memanfatkan jus ikan } \\
\text { gabus (karena kandungan } \\
\text { gizi) } \quad \text { Memanfaatkan }\end{array}$ & \\
$\quad$ - Tidak Memanfaatkan & \\
$\quad$ - & \\
\hline
\end{tabular}

Persepsi salah satu responden yang memanfaatkan kaldu dari rebusan ikan gabus menyebutkan pengalaman ini baru pertama kali dilakukan karena nilai gizi 
dan kandungan albumin baik untuk

imunitas tubuh. informasi cara pembuatan

ikan melalui wawancara mendalam

terhadap salah satu responden

menyebutkan bahwa setelah

mengkonsumsi kaldu ikan gabus tubuh terasa terdapat reaksi seperti peredaran

darah terbuka. Responden juga mengeluhkan tentang bau dan rasa (amis) dari ikan gabus menyebabkan reaksi ingin muntah saat dikonsumsi, sehingga perlu tambahan buah seperti pisang atau pemanis untuk menghilangkan rasa amis tersebut.

Proporsi responden yang ingin mencoba dan tertarik untuk mengkonsumsi jus ikan gabus $(37,5 \%)$ terlihat dari pertanyaan berulang terkait kandungan gizi yang baik untuk kesehatan khususnya bagi penderita kanker sebagai upaya preventif dan penambah asupan gizi bagi penderita kanker. Salah satu kandungan protein pada ikan gabus ini yaitu sangat kaya akan albumin yang penting bagi tubuh. Albumin diperlukan tubuh terutama dalam proses penyembuhan luka-luka. Pemberian daging ikan gabus atau ekstrak proteinnya telah dicoba untuk meningkatkan kadar albumin dalam darah dan membantu penyembuhan beberapa penyakit seperti kanker, stroke, gagal ginjal, diabetes mellitus hingga pengobatan pasca operasi
(13). Kekurangan albumin dalam tubuh manusia (hypoalbumin) menyebabkan nutrisi tidak bisa diedarkan dengan baik ke seluruh tubuh. Pemahaman tentang kandungan gizi dari ikan gabus

dipersepsikan responden menyebutkan tinggi protein dan albumin, dan berdasarkan pengalaman salah satu responden menginformasikan bahwa ikan gabus dikonsumsi oleh keluarga pada saat pasca operasi yang dipercaya mampu meningkatkan imunitas atau daya tahan tubuh. Hal ini sejalan dengan penelitian Asfar dkk, disebutkan bahwa ikan gabus dipercaya memiliki khasiat untuk pengobatan secara tradisional dan dapat meningkatkan kekebalan tubuh terutama pada anak-anak yang mengkonsumsi ikan tersebut $^{(6)}$. Manfaat lain dari albumin diperlukan pada anak-anak, kekurangan albumin akan menyebabkan terhambatnya pertumbuhan, perkembangan otak yang tidak maksimal, penurunan kekebalan tubuh hingga menyebabkan anak mudah sakit ${ }^{(13)}$. Melihat dari tingginya manfaat ikan gabus maka perlu dilakukan penelitian lebih lanjut tidak hanya dari aspek gizi tetapi juga dilakukan dalam proses penyembuhan luka, serta dapat dijadikan alternatif peningkatan asupan gizi yang bersumber pada protein hewani. 
Hubungan Persepsi Penderita Kanker Terhadap pemahaman tentang Pemanfaatan Jus Ikan Gabus

Hasil analisis uji Fisher exact test hubungan antara persepsi penderita kanker terhadap pemanfaatan jus Ikan gabus Tabel 5. menunjukkan bahwa dari 8 responden jika dihubungkan antara

persepsi penderita kanker dengan kesediaan untuk memanfaatkan jus ikan gabus dengan nilai $\mathrm{p}=0,643(\mathrm{p}>0,05)$ dan nilai odds ratio $0,5(\mathrm{OR}<1)$, maka dapat diinterpretasikan bahwa tidak terdapat hubungan yang bermakna antara persepsi penderita kanker dengan pemanfaatan jus ikan gabus. Persepsi responden memiliki peluang 0,5 kali lebih besar untuk melakukan pemanfatan ikan gabus sebagai pengobatan alternatif dibandingkan dari pada responden yang tidak berkeinginan memanfaatkan ikan gabus tersebut. semakin baik persepsi penderita kanker terhadap pengobatannya semakin besar untuk upaya menyembuhanya baik kuratif maupun preventif seperti pemanfaatan jus ikan gabus sebagai asupan gizi yang dapat meningkatkan imunitas tubuh.

Berdasarkan presentase pada tabulasi silang terdapat kecenderungan antara persepsi penderita dan pola pemanfaatan ikan gabus, meskipun responden dengan persepsi yang kurang baik $(33,3 \%)$ tetapi masih cenderung memiliki keinginan untuk memanfaatan ikan gabus untuk alternatif pengobatan bersumber dari protein hewani, hal ini disampaikan responden sebagai bentuk keingginan untuk mencoba ikan gabus tersebut. Anjuran gizi dalam terapi nutrisi oleh dokter medis yang merawat pasien juga merekomendasikan untuk mengkonsumsi ikan sebagai upaya perawatan paliatif yang baik bagi kesehatan.

Tabel 5. Hubungan persepsi penderita kanker terhadap pemanfatan Jus Ikan Gabus (Ophiocephalus Striatus) $(\mathrm{n}=8)$

\begin{tabular}{|c|c|c|c|c|}
\hline Variabel & Kategori & OR & $95 \% \mathrm{CI}$ & Nilai p \\
\hline $\begin{array}{l}\text { Pemanfaatan Jus } \\
\text { Ikan Gabus }\end{array}$ & $\begin{array}{ll}- & \text { Dimanfaatkan } \\
\text { - } & \text { Tidak dimanfaatkan }\end{array}$ & 0,5 & $0,019-12,898$ & 0,643 \\
\hline
\end{tabular}


Berdasarkan nilai odds ratio sebesar 0,5 (CI 0,019 - 12,898) dapat diartikan, besarnya peluang sampel yang memanfaatkan jus ikan gabus kandungan gizinya tinggi adalah sebesar 0,5 kali lebih besar dari pada sampel tidak memanfaatkan jus ikan gabus. perlu dilakukan penelitian lebih lanjut terkait dengan konsumsi harian jus ikan gabus bagi penderita kanker guna meningkatkan gizi dan imunitas tubuh.

\section{KESIMPULAN}

Berdasarkan hasil penelitian ini disimpulkan bahwa tidak terdapat hubungan antara persepsi penderita kanker terhadap pemanfaatan jus ikan gabus $(p>0,05)$. Namun dengan tingginya khasiat yang terdapat di ikan gabus maka penggunaan ikan gabus dapat dijadikan sebagai alternatif pengobatan yang bersumber dari protein hewani guna meningkatkan asupan gizi penderita kanker karena diketahui ikan gabus memiliki kandungan albumin yang tinggi serta memiliki kandungan asam amino esensial serta nutrisi yang baik untuk imunitas. Sehingga diharapkan dengan pemanfaatan ikan gabus sebagai terapi nutrisi suportif dapat mempercepat proses penyembuhan para penderita kanker yang menjalani perawatan paliatifnya agar dapat meningkatkan kualitas hidup pasien.

\section{SARAN}

Penting pengembangan lebih lanjut dalam bentuk serbuk instan dari ikan gabus yang dapat dikonsumsi secara praktis, mudah dan cepat penyajianya, khususnya penderita kanker untuk meningkatkan asupan gizi yang baik bagi kesehatan maupun daya tahan tubuh serta sebagai bentuk rekomendasi terapi pengobatan berbahan herbal alami dari sumber protein hewani.

\section{UCAPAN TERIMAKASIH}

Ucapan Terimakasih dan penghargaan kepada Lembaga Penelitian dan Pengabdian Masyarakat (LPPM) Universitas Islam Malang, yang telah membantu terlaksananya kegiatan penelitian ini atas bantuan dan kerjasama yang diberikan.

\section{DAFTAR PUSTAKA}

1. Syahrini, Sri. 2011. Faktor Risiko Kanker Serviks di Rumah Sakit Umum Pemerintah Dr. Wahidin Sudirohusodo Makassar, Sulawesi Selatan. Kesmas, Jurnal Kesehatan Masyarakat Nasional Vol. 5, No. 6, Juni 2011.

2. RisetKesehatanDasar

(Riskesdas), 2013. Pedoman Pewawancara Petugas Pengumpul Data. Jakarta: Badan Litbangkes, Kementerian Kesehatan RI. 
3. Subagja Indra, 2016. Kanker Serviks Pembunuh Nomor 1 Perempuan Indonesia. https://kumparan.com. Diakses tanggal 20 Juni 2017.

4. Pusat data dan Informasi Kementerian kesehatan Republik Indonesia (infodatin), 2015. Stop Kanker "situasipenyakitkanker".

Kementerian Kesehatan Republik Indonesia. Pusat Data dan Informasi. http://www.depkes.go.id

5. Zakaria C, 2015. Pengaruh Ekstrak Ikan Gabus (Channa striata) Terhadap Penyembuhan Luka Pasca Operasi Bedah Laparatomi pada Kucing (Felis domestica). Program Studi Kedokteran Hewan Fakultas kedokteran Universitas Hasanuddin. http://repository.unhas.ac.id/bitstream.

6. Asfar, Tawali, Mahendradatta, 2014. Potensi ikan gabus (channa striata) sebagai sumber makanan kesehatan. Program Doktor Ilmu Pertanian Pascasarjana Universitas Hasanuddin. Prosiding Seminar Nasional Teknologi Industri II, ISBN : 978-602-14822-1-6

7. Asfar, Tawali, Mahendradatta, 2014. Potensi ikan gabus (channa striata) sebagai sumber makanan kesehatan. Program Doktor Ilmu Pertanian Pascasarjana Universitas Hasanuddin. Prosiding Seminar Nasional Teknologi Industri II, ISBN : 978-602-14822-1-6

8. Halliwel B, Guteridge JMC, 1999. Free Radical in Biology and Medicine. $2^{\text {nd }}$ Ed. Oxford University, New York.
9. Najila MJS, Rain AN, Kamel AGM, Zahir SIS, Khozirah S, Hakim SL, Zakiah I, Azizol AK, 2002.The screeningofextractsfrom Goniothalamus scortechinii, Aralidium pinnatifidium and Andrographis paniculata for antimalarial activity using the lactate dehydrogenase assay. J. Etnopharmacology; 82:239-42.

10. Yusuf, A. M. (2014). Metode Penelitian Kuantitatif, Kualitatif, dan Penelitian Gabungan. Jakarta: Prenada Media Group.

11. Stefana, Sri Ardiningsih, 2015. Peranan dukungan pendamping dan kebiasaan makan pasien kanker selama mejalani terapi. Departemen Gizi Kesehatan Fakultas Kesehatan Masyarakat, Universitas Airlangga, Surabaya, Indonesia. Media Gizi Indonesia, Vol. 10, No. 2 JuliDesember 2015: hlm. 157-165.

12. Santoso Putra, Warnety Munir. Potensi Sari Ikan Gabus (Channa Striata ) Sebagai Nutrisi Pencerdas Otak Pada Hewan Uji Mencit Putih (Mus usculus L). Jurusan Biologi FMIPA UNAND, Kampus UNAND Limau Manis Pauh Padang. https://www.researchgate.net

13. Sadjudin, Haerudin R. 2015. Manfaat Ikan Gabus, Sumber Protein Tinggi Penyembuh Penyakit. Program Manajer Konsorsium Yayasan Badak Indonesia (YABI, WCS-IP \& YAPEKA) Siklus III TFCA-Sumatra. http://www.mongabay.co.id 